\title{
Screening of halotolerant microfungi isolated from hypersaline soils of Algerian Sahara for production of hydrolytic enzymes
}

\author{
Wassila Dendouga, ${ }^{1}$ Mohamed Belhamra ${ }^{2}$ \\ ${ }^{1}$ Laboratory of Biodiversity of Ecosystem and Dynamic Production of Agriculture System in Arid Regions (DEDSPAZA), \\ University of Biskra; ${ }^{2}$ Scientific and Technical Research Center for Arid Areas (CRSTRA), Biskra, Algeria
}

\begin{abstract}
The Algerian Sahara contains numerous hypersaline ecosystems including salt lakes in which the fungal diversity has not been characterized. The abundance and diversity of soil microofungi in three salt lakes in south-eastern Algeria was investigated together with their profiles of hydrolytic enzyme. Fungal population size and relative abundance were determined in about 75 soil samples by plate count. From 69 fungal isolates, 46.38\% were Aspergillus, $20.29 \%$ were Penicillium, and $11.59 \%$ belonged to Cladosporium genus. The 69 isolates have been studied at different constant temperatures and salinities. All fungal isolates are halotolerant or halophiles with the ability to grow at $50^{\circ} \mathrm{C}$. The screening for extracellular halophilic enzymes at $40^{\circ} \mathrm{C}$ showed
\end{abstract}

Correspondence: Wassila Dendouga, Department of Natural and Life Sciences, Faculty of Exact Sciences, Natural and Life Sciences, University of Biskra, BP 145 RP, 07000, Algeria.

E-mail: wassila.dendouga@univ-biskra.dz

Key words: Algerian Sahara; soil microfungi; hydrolase; salt tolerance; enzymes.

Acknowledgments: The authors thank Pr. Jaouani Attef (laboratory of Microbiology and Molecular Biology-Tunis) and Pr. Boureghda Houda (Laboratory of Phytopathology and Molecular Biology, National High School of Agronomy (ENSA), El-Harrach, Algiers) for their contribution to identify the fungal isolates.

Contributions: WD carried out all the experimental work (sampling, isolation, characterization and screening) and the analysis of the results, as well as the writing of the article. MB participated in the proofreading of the article.

Conflicts of interest: The authors declare no conflict of interest.

Received for publication: 4 October 2021.

Revision received: 15 December 2021.

Accepted for publication: 19 December 2021.

${ }^{\circ}$ Copyright: the Author(s), 2022

Licensee PAGEPress, Italy

Journal of Biological Research 2022; 95:10167

doi:10.4081/jbr.2022.10167

This article is distributed under the terms of the Creative Commons Attribution Noncommercial License (by-nc 4.0) which permits any noncommercial use, distribution, and reproduction in any medium, provided the original author(s) and source are credited. that $69.57 \%$ of the isolates were able to produce at least two types of the screened enzymes. Protease was the most abundant enzyme detected in $60.87 \%$ of the total isolates. The results obtained of all the growth tests indicate the adaptability of fungal isolates tested to the extreme conditions and their possible utilisation as producers of halophilic-active hydrolytic enzymes.

\section{Introduction}

Hypersaline ecosystems are typical of extreme environments that are distributed all over the earth including deep sea, salterns, solar salt and salt lakes. ${ }^{1}$ Algeria contains a large number of salt lakes, with the majority extending across the northern and eastern regions of the country. ${ }^{2}$ In Northern Africa and more specifically in Algeria, salt lakes are called chott, which is an Arabic term for dry salt depression occurring in arid regions. Chott Melghir and chott Merouane are the two largest chotts in Algerian Sahara that encompasses also several smaller salt lakes including: chott Hamraia, Eddar, Tighdidine and Tindla. ${ }^{2,3}$ These ecosystems provide a diversity of environments where different extreme conditions of salinity, solar radiation and high temperature together with low precipitation and nutrient availabilities are found. Therefore, organisms that survive in these conditions are considered as extremophiles, which most of them are microorganisms. ${ }^{4,5}$

Microbial diversity in hypersaline environments has been studied and more fully characterized for a long time, where most of these studies were focused on prokaryotic microorganisms. Although, halophilic fungi are promising models as eukaryotic organisms, their diversity has only recently been surveyed. ${ }^{6}$ Halophilic fungi like other extremophiles are fascinating organisms to be studied: they can increase our understanding of the relationship between organisms and their environment, as well as unravelling the mechanisms of their adaptation to extreme conditions. ${ }^{7,8}$ However, the halophilic behavior of most fungi isolated from hypersaline environments is different from that of halophilic prokaryotes, where halophilic fungi can adapt and grow in a wide salinity range without requiring $\mathrm{NaCl}$ for their viability. ${ }^{9}$ In addition to the knowledge of behavior and adaptation mechanisms that these fascinating organisms use to survive, halophilic fungi have attracted the attention also as novel materials for the screening of novel bioactive natural products that are highly stable and active under extreme conditions with biotechnological interests. 5,10 Recently, hydrolases and more particularly those involved in the degradation of plant materials are widely produced and exploited in diverse industrial sectors. ${ }^{11}$

The halophilic and halotolerant fungi have been found in a wide range of hypersaline environments at various geographical 
regions. ${ }^{6,7,12,13}$ However, in Algeria all aspects related to microbiota (prokaryotes and eukaryotes) are poorly investigated. For eukaryotic microbiota, Chamekh et al. ${ }^{14}$ have published the first study on fungal diversity of the Great lake of Oran, located in the north-west of Algeria, but in Algerian Sahara, excepting the report of Dendouga et al. ${ }^{15}$ conducted in 2011 and 2012, no studies of fungal content have been undertaken to date. Therefore, this study was carried out to investigate the fungal diversity in three salt lakes located in the north-east of Algerian Sahara, which were the subject of the previous study. The extracellular hydrolases production by the obtained isolates, their temperature and salt tolerances were also studied as indication of their adaptation to the extreme environment.

\section{Materials and Methods}

\section{Site description and soil sampling}

This work was carried out in three salt lakes, namely: chott Merouane, chott Melghir and chott Tighdidine located in the northeast of the Algerian Sahara (Figure 1). The main characteristics of the studied area are summarized in Table 1 . Soil samples $(200 \mathrm{~g})$ were collected in October 2014 from five different points around each salt lake at a depth of 10 to $30 \mathrm{~cm}$. Five $\mathrm{cm}$ soil from the ground surface was firstly removed to avoid contamination. The collected soil samples were transported to the laboratory and stored at $4^{\circ} \mathrm{C}$ for no more than $48 \mathrm{~h}$.

Table 1. Main characteristics of the investigated sites.

\begin{tabular}{|c|c|c|c|}
\hline Characteristics & Site A (chott Merouane) & Site B (chott Melghir) & Site C (chott Tighdidine) \\
\hline Latitude & $34^{\circ} 02.433^{\prime}$ & $34^{\circ} 10.631^{\prime}$ & $33^{\circ} 31.366^{\prime}$ \\
\hline Longitude & $05^{\circ} 58.748^{\prime}$ & $06^{\circ} 17.322^{\prime}$ & $06^{\circ} 02.181^{\prime}$ \\
\hline Tmax & $50^{\circ} \mathrm{C}$ & $55^{\circ} \mathrm{C}$ & $50^{\circ} \mathrm{C}$ \\
\hline Soil type & Clay & Clay & Sandy-clay \\
\hline $\mathrm{EC}(\mathrm{ms} / \mathrm{cm})$ & 20.87 & 29.45 & 18.44 \\
\hline $\mathrm{pH}$ & 7.73 & 7.89 & 8.97 \\
\hline OM $(\%)$ & 0.67 & 0.26 & 0.46 \\
\hline
\end{tabular}

Tmax: Maximum temperature (in July-August), EC: Electrical conductivity at $25^{\circ} \mathrm{C}, \mathrm{OM}$ : Organic matter.

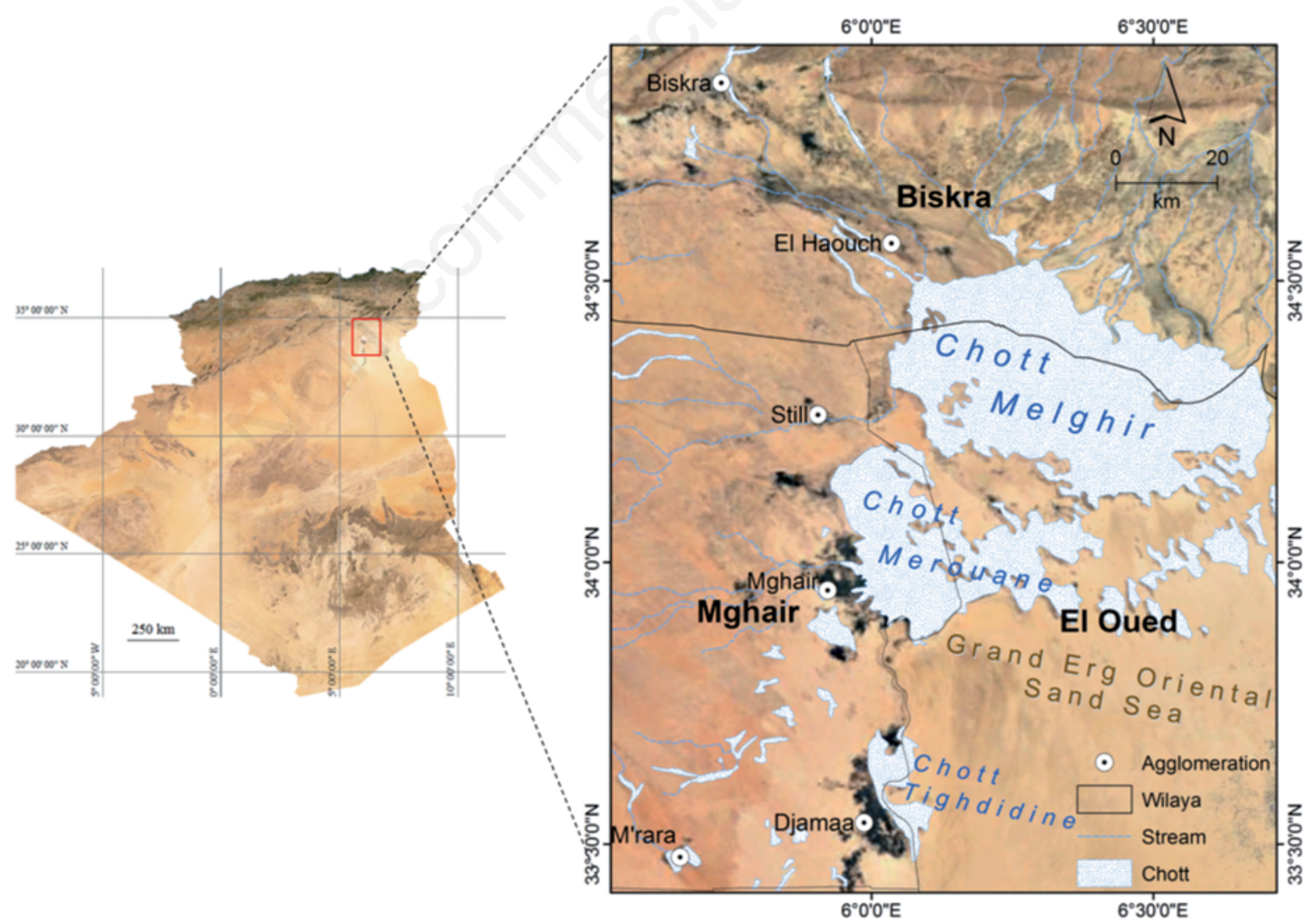

Figure 1. Geo-localization map of the study area showing the three salt lakes (chott Melghir, chott Merouane and $c h o t t$ Tighdidine), located in the Oued Righ Valley (Low Algerian Sahara). Intermittent streams and chott limits were digitized and superimposed on natural color Landsat 8 OLI image dated 2018 (www.usgs.gov). 


\section{Isolation and identification of fungi}

Fungi were isolated on Potato Dextrose Agar (PDA) containing $10 \%$ of $\mathrm{NaCl}$ and $50 \mathrm{mg} / \mathrm{L}$ of chloramphenicol using the soil dilution plate method. ${ }^{16}$ This method is especially applicable to desert soils, where fungi may exist for a long period in a dormant state (spore). The plates were incubated at $35^{\circ} \mathrm{C}$, and examined daily for developing colonies. All fungal colonies appearing on the plates were counted and purified using the single spore technique. Fungal isolates were identified at species level based initially on phenotypic approaches. Morphological identification was performed by observation of colony characteristics on selective media recommended to each genus and by microscopic observations, especially of reproductive structures. Phenotypic results were compared to the taxonomic keys. ${ }^{17,18,19}$ Phenotypic characterization of some isolates was completed by molecular identification by sequencing the ITS1-5.8S-ITS2 rRNA region using the primers ITS1 and ITS4. ${ }^{22}$

\section{Physiological characterization of fungi}

Salt tolerances were determined by the dry weight estimation method. ${ }^{21}$ Agar plugs of $5 \mathrm{~mm}$ of diameter obtained from a fungal pre-culture in PDA were inoculated into PDB supplemented with various $\mathrm{NaCl}$ concentrations from 0 to $25 \%$ with $5 \%$ intervals. The cultures were grown in $250 \mathrm{~mL}$ Erlenmeyer flasks containing $50 \mathrm{~mL}$ of PDB medium with constant shaking (120rpm) for 15 days. Temperature tests were done following the same procedure as salinity, by incubating inoculated medium supplemented with $10 \%$ of $\mathrm{NaCl}$ at $5,15,20,40,45,50$ and $55^{\circ} \mathrm{C}$.

\section{Fungal screening for extracellular hydrolytic enzymes}

Extracellular enzyme production was screened on minimal agar medium containing $10 \%$ of total salt and the substrate for each hydrolytic activity as inducer. ${ }^{24}$ Substrates with their concentrations were as follows: $0.2 \%$ of soluble starch for amylase production, $1 \%$ of carboxymethylcellulose for cellulase, $0.3 \%$ of chitin for chitinase, $1 \%$ of skim milk powder for protease, and $1 \%$ Tween 20 with $0.01 \% \mathrm{CaCl}_{2}$ for lipase. Inoculation was made by transferring agar plugs of each fungal isolate at the center of corresponding medium. All fungal tests were prepared in triplicate and non-inoc- ulated plates with substrates were used as negative controls. Plates were incubated at $40^{\circ} \mathrm{C}$ for 5-10 days. After incubation, the plates were examined for the presence of a clear zone around the fungal colony, indicating extracellular hydrolase activity. Cellulase and amylase activities were revealed by flooding the plates with Congo red and Lugol's solution, respectively.

\section{Results}

\section{Abundance of soil microfungi}

A total of 69 microfungal isolates belonging to 11 genera were obtained in this study. Aspergillus and Penicillium were the most abundant genera and they were occurred almost in all samples examined, comprising $46.38 \%$ and $20.29 \%$ of total fungi, respectively. Cladosporium was also an abundant genus especially in chott Melghir (site B), representing $11.59 \%$ of the total isolate number (Figure 2). In addition, Aspergillus was the highest diverse fungal genus with 8 species. Species more frequently isolated were A. niger (14.49\%), A. fumigatus (10.14\%), and P. minioluteum (8.69\%). Among melanized fungi, Cladosporium cladosporioides was the most prevalent species $(7.25 \%)$, and appeared in the three sites. Isolates belonging to the genera Trichoderma and Chaetomium witch present a low relative abundance appeared only in one site. Seven black sterile mycelia were also isolated.

\section{Effect of salt and temperature on fungal growth}

To study the salt tolerance of fungal isolates, each one was grown at different concentrations of $\mathrm{NaCl}$; measurement results of mycelial dry weight are presented in Figure 3. The majority of isolates tested in this study are halotolerant, and were able to grow at salinity ranging $0-15 \% \mathrm{NaCl}$, with optimum growth at $10 \%$ of $\mathrm{NaCl}$. While four isolates are categorized as halophilic fungi, they were not able to grow in the absence of salt and showed their optimal growth at $10-15 \%$ of $\mathrm{NaCl}$. Alternaria alternata (1) and Cladosporium cladosporioides (3) halophilic isolates tolerated $20 \%$ of $\mathrm{NaCl}$. Based on temperature results, all tested isolates were capable of growing in the range of 20 to $50^{\circ} \mathrm{C}$ (Figure 3). The majority of isolates obtained in this study are

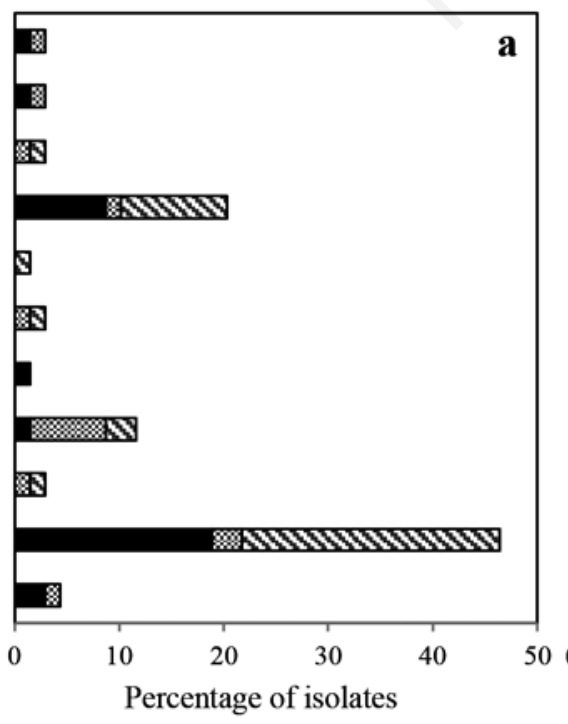

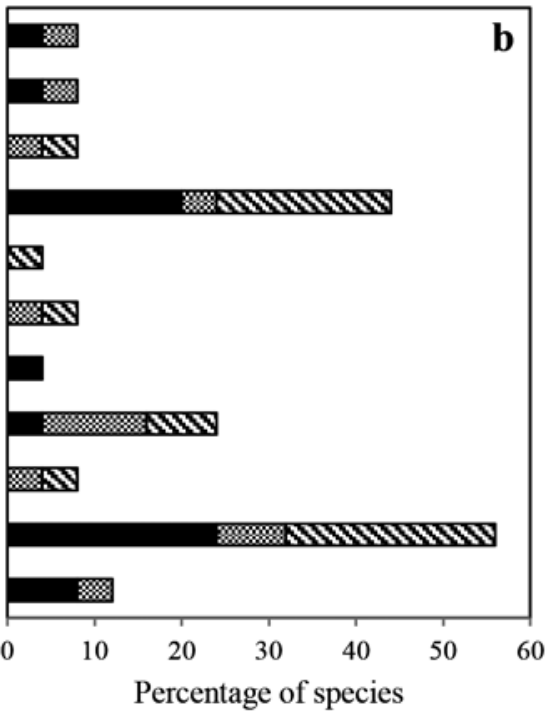

Site A
Site B
@ Site C

Figure 2. Relative abundance of microfungi (a: $\%$ of total isolate number, $b$ : $\%$ of total species number) isolated from soil around three Algerian salt lakes (site A: chott Merouane; site B: chott Melghir; site C: chott Tighdidine) during October 2014. 
thermotolerant; they were able to grow at temperatures in the range 5 to $50{ }^{\circ} \mathrm{C}$, with optimal growth at $40{ }^{\circ} \mathrm{C}$. However, only three isolates corresponding to Alternaria (1) and Ulocladium (2) genera can be considered as thermophilic fungi based on their inability to grow at $<20{ }^{\circ} \mathrm{C}$. These isolates have preserved $50 \%$ of their grow biomass at $55{ }^{\circ} \mathrm{C}$.

\section{Screening for halophilic extracellular enzymes}

Sixty-nine fungal isolates were tested on solid media to screen amylase, cellulase, chitinase, protease and lipase activities in the presence of $10 \% \mathrm{NaCl}$ (Table 2). The results obtained showed that $69.57 \%$ of the isolates displayed at least two of the five-screened activities. Protease was the most abundant activity detected in $60.87 \%$ of the total isolates. Amylase, cellulase and chitinase were detected in an important number of Aspergillus and Penicillium isolates with $49.28 \%, 47.83 \%$ and $42.03 \%$ of the total isolates respectively. However, lipase activity was less frequently detected than the other hydrolytic activities with $5.80 \%$ of the total fungal isolates.

\section{Discussion}

The first objective of the present research was to study the abundance and diversity of fungi in soil around three salt lakes in Algerian desert. Dendouga et al. ${ }^{15}$ published the first report on the edaphic factors affecting the distribution of soil fungi in these three salt lakes, which present an extreme environment, particularly because of its salinity. A difference is noticed between the three sites in the number of fungal isolates, explained probably by the salinity of soil, the poorest site is chott Melghir, known by its highest salt level. In fact, salts concentration as a major factor affecting soil microbial abundance has been the subject of several studies. ${ }^{10,12,15}$ In saline soil, osmotic stress and toxic ions result in drying and lysis of cells which reduce soil biomass. ${ }^{23}$ In this study, we have characterized 69 isolates of microfungi belonging to 25 species dispatched into 11 genera. From this collection, Aspergillus and Penicillium were the predominant genera in chott Merouane (site A) and chott Tighdidine (site C); however

Table 2. Screening result of the extracellular halophilic-active hydrolytic enzymes.

\begin{tabular}{lcccccc}
\hline Genus & Abundance & Amylase & Cellulase & Chryymatic activities (N/\%) & Protease & Lipase \\
Alternaria & $3(4.35)$ & $1(1.45)$ & 0 & 0 & $3(4.35)$ & 0 \\
Aspergillus & $32(46.38)$ & $17(24.64)$ & $22(31.88)$ & $17(24.64)$ & $13(18.84)$ & $1(1.45)$ \\
\hline Aureobasidium & $2(2.90)$ & 0 & 0 & 0 & $2(2.90)$ & 0 \\
Cladosporium & $8(11.59)$ & $3(4.35)$ & $1(1.45)$ & $2(2.90)$ & $7(10.14)$ & $1(1.45)$ \\
\hline Chaetomium & $1(1.45)$ & $1(1.45)$ & $1(1.45)$ & 0 & 0 & 0 \\
Curvularia & $2(2.90)$ & 0 & 0 & 0 & $2(2.90)$ & 0 \\
\hline Trichoderma & $1(1.45)$ & 0 & 0 & 0 & 0 & 0 \\
Penicillium & $14(20.29)$ & $12(17.39)$ & $8(11.59)$ & $10(14.49)$ & $10(14.49)$ & $1(1.45)$ \\
\hline Phialophora & $2(2.90)$ & 0 & $1(1.45)$ & 0 & $2(2.90)$ & 0 \\
Phoma & $2(2.90)$ & 0 & 0 & 0 & $1(1.45)$ & $1(1.45)$ \\
\hline Ulocladium & $2(2.90)$ & 0 & 0 & 0 & $2(2.90)$ & 0 \\
Overall & $69(100)$ & $34(49.28)$ & $33(47.83)$ & $29(42.03)$ & $42(60.87)$ & $4(5.80)$ \\
\hline
\end{tabular}
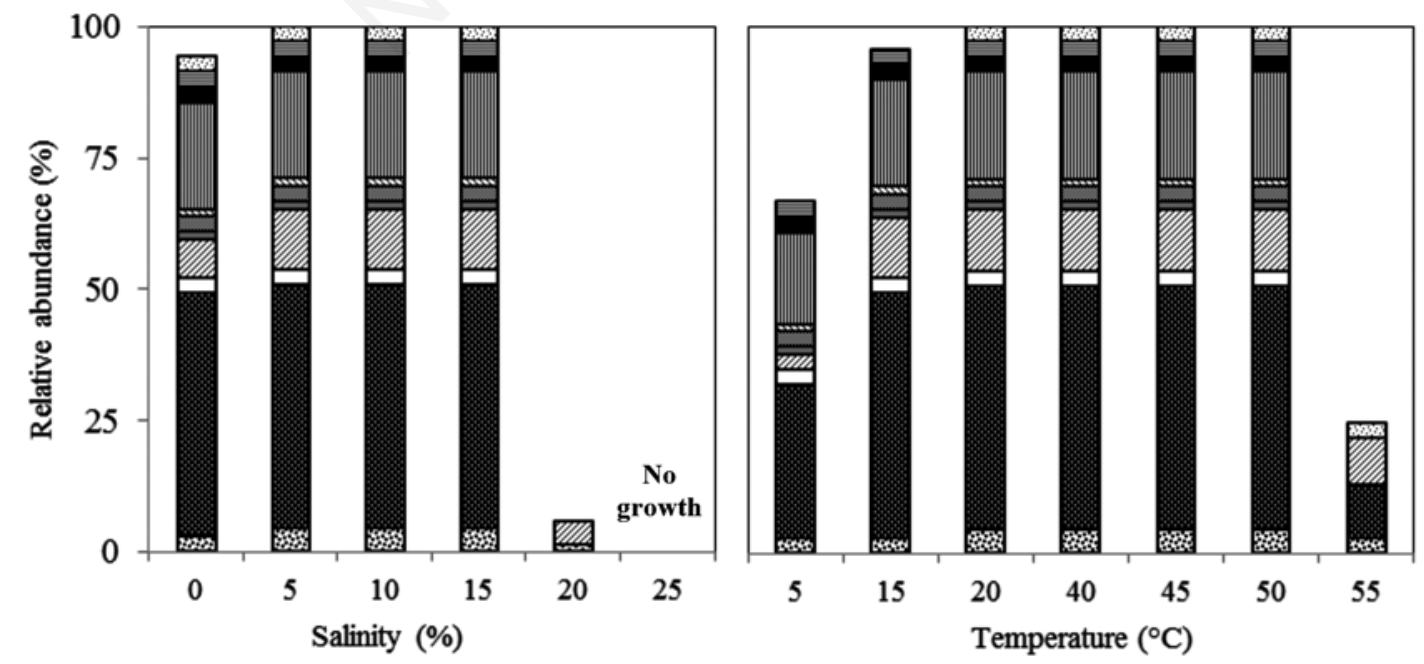

ㅂlocladium

口Phoma

- Phialophora

口Penicillium

هTrichoderma

口Curvularia

口Chaetomium

- Cladosporium

$\square$ Aureobasidium

Aspergillus

- Alternaria

Figure 3. Effect of salt concentration and temperature on fungal isolates growth. 
Cladosporium isolates were obtained particularly from chott Melghir (site B). Our results are in agreement with other studies, which reported that the abundance of melanized fungi seems directly proportional to salt concentration, and at low salinity these fungi are replaced by moniliaceous fungi, where Aspergillus and Penicillium are the dominant. ${ }^{12,24}$ Concerning the prevalent species, the present study revealed that $A$. niger, A. fumigatus, $P$. minioluteum and $C$. cladosporioides were the most predominant species and common in the three sites. This result was supported by several studies conducted in desert and saline environments; their dominance suggests that these species are highly adaptable to extreme conditions. ${ }^{13-15,25,26}$

The second objective of the present research was the physiological and biochemical characterization of these fungal isolates. This can contribute to understanding the environmental functions of fungi and their ecological adaptation to extreme habitats, as well as the prediction of their potential biotechnological applications. Regarding the stress of salinity, most fungal isolates obtained in this study were moderate halotolerant; they grew in absence of salinity with optimum growth at moderate concentration $(10 \%)$ of $\mathrm{NaCl} .27$ However, only four isolates can be considered as halophilic fungi, they have the capacity to grow at high concentration of $\mathrm{NaCl}(20 \%)$ with their inability to grow in the absence of salt. All halophilic fungi occurred in the present study were isolated from chott Melghir; these results coincide with the high values of conductivity in this site. Nevertheless, halotolerant and halophilic filamentous fungi obtained in the present research are mainly cosmopolitan genera and are known to be distributed worldwide occurring in different soil types. These findings support the conclusion that saline and arid soils do not harbor a characteristic mycobiota of specialized taxa. ${ }^{7,28}$ On the other hand, temperature tolerance tests showed that the majority of isolates were thermotolerant, growing in the range of 5 to $50^{\circ} \mathrm{C}$. The minimum and maximum growth temperatures are used to distinguish between thermotolerant and thermophilic fungi. ${ }^{29,30}$ Based on these references, and particularly with regard to the minimum growth temperature, only three unidentified isolates belonging to Alternaria (1) and Ulocladium (2) genera are classified as thermophilic fungi by their ability to grow at $55^{\circ} \mathrm{C}$, with their lowest biomass production at $20^{\circ} \mathrm{C}$. However, they were retained $100 \%$ of the biomass production at $40^{\circ} \mathrm{C}$ such as thermotolerant isolates. It is not surprising that the majority of isolates grow best at high temperatures in view of their origin environment. This characteristic with their ability to grow at low temperature, may allow them to better adapt to the strong thermal fluctuations in desert environments. ${ }^{31}$ Of particular interest, the four halophilic isolates belonging to Alternaria alternata ( 1 isolate) and Cladosporium cladosporioides (3 isolates) species, the same have presented a high biomass at $50{ }^{\circ} \mathrm{C}$. These species were described by previous studies carried out in saline desert environment as haloand thermophilic melanized fungi. ${ }^{6,32}$ The dominance of melanized species that are characterized by the presence of melanin pigment in their cell walls and spores is considered as an adaptive strategy of soil fungi to harsh desert climatic and edaphic conditions. ${ }^{26}$ It has proved that under extreme conditions, including high irradiation levels and salt concentrations, melanin granules are more densely packed than in normal conditions that allow them to exert their protective function. That's why melanized fungi exhibit improved resistance to dehydration, and solar radiation, better than the moniliaceous fungi whose cells are devoid of melanin. ${ }^{33,34}$ In addition, stress condition induced changes in lipid composition in the fungal cell membrane, and especially an increase in fatty acid unsaturation, which provides and maintains the right degree of fluidity necessary for membrane function. ${ }^{32,35}$
The ability of fungi to synthesize essential compounds and energy requires the production of enzymes involved in the degradation and use of organic matter. We therefore tested the production of five extracellular hydrolases in the presence of $10 \%$ of $\mathrm{NaCl}$ at $40{ }^{\circ} \mathrm{C}$ by 69 isolates, as an indication of their adaptation to the extreme environment. Enzymes tested in the current study were: amylase, that catalyses the hydrolysis of starch, the major carbohydrate reserve in higher plants; protease, an enzyme involved in the degradation of plant and animal proteins; cellulase, which catalyses the decomposition of cellulose, the most abundant component in the biosphere; chitinase, an hydrolytic enzyme responsible of chitin breakdown, which is a primary component of fungal cell walls; finally, lipolytic enzymes whose biological function is to catalyse the hydrolysis of triacylglycerols. The obtained results showed that the majority of isolates produced at least two tested enzymes. This result can be considered as a proof of the ability of halophilic and halotolerant fungi to use several organic substrates. In terms of abundance, these tests have also shown the abundance of some enzymes compared to the other hydrolytic activities. Protease was the most frequently detected activity under the tested conditions. Similar results on fungal isolates from saline environments have shown high caseinase activities with little effect of salinity on enzyme production. ${ }^{25}$ Amylase, cellulase and chitinase, which are ranked second after protease with almost equal abundance, were detected in an important number of isolates belonging to Aspergillus and Penicillium, the most abundant and diverse genera. In this context, it has been reported that these ubiquitous fungi, which are able to grow even in extreme environments, are the most important microorganisms contributing to the decomposition of organic materials, ${ }^{36,37}$ and their extracellular enzyme profiles can be a useful technique for their chemotaxonomy. ${ }^{37,38}$ From lipase test, we have observed that only four isolates from different genera exhibited lipase activity; we have also deduced that no clear correlation exists between growth and enzyme production, where some isolates have shown high colony diameter without clear zones. The positive growth with negative enzyme production may be explained by the ability of the fungus to use other materials in the medium rather than the test substrate, or that the medium inhibits its detection. ${ }^{39}$

\section{Conclusions}

In conclusion, fungal species described in the three salt lakes are common with similar studies on fungi from saline and desert environments with the dominance of melanized fungi in the most saline site, this dominance can be considered as an adaptive strategy of soil microfungi to harsh these conditions. However, further studies are necessary to understand fungal communities' composition and their adaptation mechanisms in these habitats. The obtained results showed also that Algerian salt lakes can serve as a source of isolation of halotolerant and halophilic fungi, which could be considered as potential producers of halophilic-active hydrolytic enzymes.

\section{References}

1. Oren A. Molecular ecology of extremely halophilic archaea and bacteria. FEMS Microbiol Ecol 2002;39:1-7.

2. Demnati F, Samraoui B, Allache, F et al. A literature review of 
Algerian salt lakes: values, threats and implications. Environ Earth Sci 2017;76:127-42.

3. Mahowald NM, Bryant RG, Corral J, Steinberger L. Ephemeral lakes and desert dust sources. Geophys Res Let 2003;30:46-9.

4. Ventosa A, Nieto JJ. Biotechnological applications and potentialities of halophilic microorganisms. World J Microbiol Biotechno 1995;11:85-94.

5. Anitori RP. Extremophiles: Microbiology and biotechnology. Caister Academic Press, Norfolk, UK, 2012.

6. Gunde-Cimerman N, Zalar P. Extremely halotolerant and halophilic fungi inhabit brine in solar salterns around the globe. Food Technol Biotechnol 2014;52:170-9.

7. Grishkan I, Nevo E, Wasser SP. Soil micromycete diversity in the hypersaline Dead Sea coastal area, Israel. Mycol Prog 2003;2:19-28.

8. Gunde-Cimerman N, Ramos J, Plemenitaš A. Halotolerant and halophilic fungi. Mycol Res 2009;113:1231-41.

9. Plemenitaš A, Vaupotič T, Lenassi $M$ et al. Adaptation of extremely halotolerant black yeast Hortaea werneckii to increased osmolarity: a molecular perspective at a glance. Stud Mycol 2008;61:67-75.

10. Zhang WW, Wang C,Xue R, Wang LJ. Effects of salinity on the soil microbial community and soil fertility. J Integr Agric 2019;18:1360-8.

11. Van den Brink J, De Vries R.P. Fungal enzyme sets for plant polysaccharide degradation. Appl. Microbiol Biotechnol 2011;91:1477-92.

12. Cantrell SA, Casillas-Martinez L, Marirosa M. Characterization of fungi from hypersaline environments of solar salterns using morphological and molecular techniques. Mycol Res 2006;110:962-70.

13. Jaouani A, Neifar M, Prigione V, et al. Diversity and enzymatic profiling of halotolerant micromycetes from sebkha El Melah, a Saharan salt flat in southern Tunisia. Biomed Res Int 2014;2014:439197.

14. Chamekh R, Deniel F, Donot C, et al. Isolation, identification and enzymatic activity of halotolerant and halophilic fungi from the great Sebkha of Oran in North western of Algeria. Mycobiology 2019;47:230-41.

15. Dendouga W, Boureghda H, Belhamra M. Edaphic factors affecting distribution of soil fungi in three Chotts located in Algerian desert. Courrier du Savoir 2015;19:147-52.

16. Davet P, Rouxel F. Détection et isolement des champignons du sol. INRA, Paris, 1997.

17. Domsch KH, Gams W, Anderson TH. Compendium of soil fungi. Academic Press London, UK; 1980.

18. Botton B, Breton A, Fevre M et al. Moisissures utiles et nuisibles importance industrielle. Masson, Paris; 1990.

19. Watanabe T. Pictorial atlas of soil and seed fungi: morphologies of cultured fungi and key to species. CRC Press, Boca Raton, USA. 2002.

20. White TJ, Bruns T, Lee S, Taylor J. Amplification and direct sequencing of fungal ribosomal RNA genes for phylogenetics. In PCR Protocols: A guide to methods and applications, Innis MA, Gelfand DH, Sninsky JJ, White TJ (eds). Academic Press, San Diego, USA, 1990; pp. 315-322.
21. Phillips MW, Gordon GLR. Growth characteristics on cellobiose of three different anaerobic fungi isolated from the ovine rumen. Appl Environ Microbiol 1989;55:1695-1702.

22. Hankin L, Anagnostakis SL. The use of solid media for detection of enzyme production by fungi. Mycologia 1975;67:597-607.

23. Yan N, Marschner P, Cao W, et al. Influence of salinity and water content on soil microorganisms. ISWCR 2015;3:316-23.

24. Butinar L, Sonjak S, Zalar P, et al. Melanized halophilic fungi are eukaryotic members of microbial communities in hypersaline waters of solar salterns. Bot Mar 2005;48:73-9.

25. Molitoris HP, Buchalo AS, Kurchenko I, et al. Physiological diversity of the first filamentous fungi isolated from the hypersaline Dead Sea. Fungal Divers 2000;5:55-70.

26. Grishkan I, Nevo E. Spatiotemporal distribution of soil microfungi in the Makhtesh Roman area, central Negev desert. Israel Fungal Ecol 2010;3:326-37.

27. Kushner DJ. Microbial life in extreme environments. Academic press, London, UK; 1978.

28. Evans S, Hansen RW, Schneegurt MA. Isolation and characterization of halotolerant soil fungi from the great salt plains of Oklahoma. Cryptogam Mycol 2013;34:329-41.

29. Cooney DG, Emerson R. Thermophilic Fungi. W. H. Freeman and company, San Francisco; 1964.

30. Maheshwari R, Bharadwaj G, Bhat MK. Thermophilic fungi: their physiology and enzymes. Microbiol Mol Biol Rev 2000;64:461-88.

31. Selbmann L, de Hoog GS, Mazzaglia A et al. Fungi at the edge of life: cryptoendolithic black fungi from Antarctic desert. Stud Mycol 2005;5:1-32.

32. Méjanelle L, Lòpez JF, Gunde-Cimerman N, Grimalt JO. Ergosterol biosynthesis in novel melanized fungi from hypersaline environments. J Lipid Res 2001;42:352-60.

33. Plemenitaš A, Gunde-Cimerman N. Cellular responses in the halophilic black yeast Hortaea werneckii to high environmental salinity. In Adaptation to life at high salt concentrations in archaea, bacteria, and eukarya; Gunde-Cimerman N, Oren A, Plemenitaš A (eds.). Springer, Netherlands, 2005; pp. 453-470.

34. Grishkan I. Ecological stress: Melanization as a response in fungi to radiation. In Horikoshi K, Antranikian G, Bull A, et al. (eds). Extremophiles Handbook. Springer, Tokyo, 2011; pp. 1137-1145.

35. Turk M, Méjanelle L, Sentjurc M et al. Salt-induced changes in lipid composition and membrane fluidity of halophilic yeast-like melanized fungi. Extremophiles 2004;8:53-61.

36. De Vries RP, Visser J. Aspergillus enzymes involved in degradation of plant cell wall polysaccharides. Microbiol Mol Biol Rev 2001;65:497-522.

37. Tsang CC, Tang YMJ, Lau SKP, Woo PCY. Taxonomy and evolution of Aspergillus, Penicillium and Talaromyces in the omics era-Past, present and future. Comput Struct Biotechnol J 2018;16:197-210.

38. Meijer M, Houbraken JAMP, Dalhuijsen S et al. Growth and hydrolase profiles can be used as characteristics to distinguish Aspergillus niger and other black aspergilli. Stud Mycol 2011;69:19-30.

39. Abdel-Raheem A, Shearer CA. Extracellular enzyme production by freshwater ascomycetes. Fungal Divers 2002;11:1-19. 